Article

\title{
Insecticidal Activities Against Odontotermes formosanus and Plutella xylostella and Corresponding Constituents of Tung Meal from Vernicia fordii
}

\author{
Hui Zhang ${ }^{1,2,3,4} \mathbb{D}^{\text {, Guilin Chen }}{ }^{1,3,4}$, Shiyou Lü ${ }^{5}\left(\mathbb{D}\right.$, Lin Zhang ${ }^{6}$ and Mingquan Guo ${ }^{1,3,4, *}$ \\ 1 CAS Key Laboratory of Plant Germplasm Enhancement and Specialty Agriculture, Wuhan Botanical Garden, \\ Chinese Academy of Sciences, Wuhan 430074, China; zhanghui183@mails.ucas.ac.cn (H.Z.); \\ glchen@wbgcas.cn (G.C.) \\ 2 Institute of Geochemistry, University of Chinese Academy of Sciences, Beijing 100049, China \\ 3 Sino-Africa Joint Research Center, Chinese Academy of Sciences, Wuhan 430074, China \\ 4 Innovation Academy for Drug Discovery and Development, Chinese Academy of Sciences, \\ Shanghai 201203, China \\ 5 State Key Laboratory of Biocatalysis and Enzyme Engineering, School of Life Sciences, Hubei University, \\ Wuhan 434200, China; shiyoulu@hubu.edu.cn \\ 6 Key Laboratory of Cultivation and Protection for Non-Wood Forest Trees, Ministry of Education, \\ Central South University of Forestry and Technology, Changsha 410004, China; triwoodtim918@126.com \\ * Correspondence: guomq@wbgcas.cn; Tel.: +86-027-87700850
}

check for updates

Citation: Zhang, H.; Chen, G.; Lü, S.; Zhang, L.; Guo, M. Insecticidal Activities Against Odontotermes formosanus and Plutella xylostella and Corresponding Constituents of Tung Meal from Vernicia fordii. Insects 2021, 12, 425. https://doi.org/10.3390/ insects12050425

Academic Editors: Francisco

José Beitia and Estrella

Hernández Suárez

Received: 9 April 2021

Accepted: 5 May 2021

Published: 10 May 2021

Publisher's Note: MDPI stays neutral with regard to jurisdictional claims in published maps and institutional affiliations.

Copyright: (C) 2021 by the authors. Licensee MDPI, Basel, Switzerland This article is an open access article distributed under the terms and conditions of the Creative Commons Attribution (CC BY) license (https:// creativecommons.org/licenses/by/ $4.0 /)$
Simple Summary: Odontotermes formosanus (Shiraki) (O. formosanus) and Plutella xylostella (Linnaeus) (P. xylostella) are common industrial and agricultural pests with a wide distribution range, multiple host species, few natural predators, and rapid reproduction. The control of these pests relies heavily on synthetic chemical pesticides; however, environmental pollution and the rise of insect resistance induced by the excessive use of synthetic chemical pesticides pose serious challenges. The present study was designed to systematically evaluate the insecticidal activities of different extracts of tung meal against the above two pests and to reveal the chemical constituents of the main active parts. The result confirmed the remarkable insecticidal activity of tung meal and provided a theoretical basis for its development as a potential plant insecticide.

Abstract: The environmental pollution, pesticide resistance, and other associated problems caused by traditional chemical pesticides with limited modes of action make it urgent to seek alternative environmentally-friendly pesticides from natural products. Tung meal, the byproduct of the detoxified Vernicia fordii (Hemsl.) seed, has been commonly used as an agricultural fertilizer and as a pesticide. However, its active insecticidal extracts and ingredients remain elusive. In the present study, the contact toxicities of tung meal extracts against the agricultural and forest pests like $O$. formosanus and P. xylostella were examined. Our results showed that ethyl acetate and petroleum ether extracts showed the strongest toxicity against $O$. formosanus and P. xylostella, respectively. In order to further explore the chemical profiles of the ethyl acetate and petroleum ether extracts, UPLC-Q/TOFMS and GC-MS analyses have been performed, and 20 and 29 compounds were identified from EA and PE extracts, respectively. The present study, for the first time, verified the noteworthy insecticidal activities on the aforementioned agricultural and forest pesticides and revealed the potential active parts and chemical composition, which are conducive to further exploiting the potential of tung meal as a natural plant-derived insecticide for biological control of agricultural and forest pests.

Keywords: euphorbiaceae; insecticidal activities; plant extracts; botanical pesticide; biological control

\section{Introduction}

Vernicia fordii (Hemsl.) Airy Shaw, a subtropical perennial industrial crop, is widely distributed in the east of Asia. It originated from China and is also known as tung oil 
tree. Phytochemical investigations on $V$. fordii have revealed the presence of fatty acids, lignans, terpenes, polyphenols, flavonoids, etc. [1]. As an industrial manufacture material, tung oil is often used for paints and coatings, and has also been developed as a renewable bioenergy source with great potential [2]. In particular, tung meal, the by-product of the de-oiling of tung seeds, is commonly used as fertilizer in agriculture due to its rich protein and nutrient content [3]. On the one hand, there are some limitations of tung meal in agriculture due to its toxic ingredients [4,5]; on the other hand, it has been revealed that the extracts of tung meal exhibited excellent insecticidal effects against some agricultural pests, like Enchytraeus bulbosu. However, there are few systematic studies focusing on its insecticidal activities and components [6,7]. To this end, it is of great importance to identify the effective insecticidal potential and the main components of tung meal for its further development in agriculture as natural insecticides.

Odontotermes formosanus (O.formosanus) belonging to Isoptera, also known as termitidae, is characterized by fast reproduction speed, wide distribution range, and high destructive power. This insect mainly harms gardens, trees, buildings, and dams, thus posing a serious threat to the wildlife, human health, and world forestry economy [8]. Statistically, more than $\$ 40$ billion losses are caused directly or indirectly by termites annually, and termitidae has become one of the five major pests in the world [9]. Plutella xylostella (P. xylostella) is a widespread omnivorous insect belonging to the Lepidoptera and Plutellidae [10]. It has been one of the most harmful pests to cruciferous vegetables in many countries worldwide due to its numerous host species, few natural predators, pesticide resistance, and rapid reproduction rate, and there remain great challenges to be confronted in the control of $P$. xylostella [11,12].

At present, the chemical control of these pests is still primarily based on the use of synthetic chemical pesticides, which have been sustained over many decades. However, diverse challenges are faced due to the excessive usage of traditional synthetic pesticides, such as pesticide residues, susceptibility to pesticide resistance, environmental and human health problems [13]. For example, current highly toxic drugs to control termites mainly include imidacloprid, cypermethrin, permethrin, fipronil, etc. In addition, P. xylostella has developed resistance to a variety of insecticidal chemicals, including pyrethroids, carbamate, organic fluidics, organochlorines, abamectin, polyfungicides, and even Bacillus thuringiensis, which makes it increasingly difficult and costly to control. With the banning of highly toxic insecticides and the increasing resistance to some commonly used insecticides, finding environment-friendly biological pesticides is now becoming particularly urgent [14].

The ecological and human health problems caused by chemical pesticides have been prompting extensive searches for environment-friendly biological pesticides [15]. Medicinal plant resources are abundant and easy to obtain. Extracting high-efficiency, biodegradable, and low-toxicity or non-toxic active ingredients from medicinal plants for pest management can not only reduce environmental pollution, but also be helpful in reducing pesticide resistance [16]. In addition, compared with traditional insecticides, plant-derived insecticides also have some other advantages like leaving no residue, various types and modes of action, etc., which play a positive role in solving the problems caused by chemical pesticides $[17,18]$. Considering the necessity and urgency for the development of environment-friendly bio-insecticides, this research aimed to investigate the insecticidal activities of tung meal against the above two pests and reveal the chemical constituents of the extracts with the strongest toxicity [5]. The results provide further practical guidance for the agricultural application and development of tung meal as both natural plant-based insecticides and organic fertilizers.

\section{Materials and Methods}

\subsection{Collection and Rearing of Insects}

The O. formosanus was collected from Shizishan, Hongshan district, Wuhan city, Hubei province. They were kept in a box $(30 \times 15 \times 15 \mathrm{~cm})$ in a dark environment of $25 \pm 1{ }^{\circ} \mathrm{C}$ 
and $70 \pm 5 \%$ RH (relative humidity). The larvae of P. xylostella (Linnaeus) were purchased from Henan Jiyuan Baiyun Industry Co., and grown in a culture chamber at $27 \pm 1{ }^{\circ} \mathrm{C}$ and $60 \pm 10 \% \mathrm{RH}$; the illumination period was $14 \mathrm{~L}: 10 \mathrm{D}$.

\subsection{Acquisition of Plant Materials and Extracts}

Tung meal of V. fordii Hemsl. was collected from Qingping in June 2018, Hunan province. The specimen was kindly authenticated by plant taxonomist professor Guangwan $\mathrm{Hu}$ and deposited at Wuhan Botanical Garden, Chinese Academy of Sciences. Firstly, $3 \mathrm{~kg}$ of dry tung meal powder was soaked in $15 \mathrm{~L}$ of $95 \%$ ethanol for $11 \mathrm{~h}$. Then, ultrasonic extraction was performed in triplicate at $200 \mathrm{~W}$ and $40 \mathrm{KHz}$ for $30 \mathrm{~min}$, and the extracts were concentrated into crude syrup residues using a rotary evaporator. Later, the crude extracts (CE) were dispersed in water and partitioned with petroleum ether (PE), dichloromethane (DCM), ethyl acetate (EA), and n-butanol (n-Bu) successively, the remaining water layer was the aqueous extraction part $\left(\mathrm{H}_{2} \mathrm{O}\right)$. Finally, the corresponding dry extracts were obtained after freeze-drying. For the following LC-MS analysis, the EA extracts were re-dissolved with methanol and then filtered with a $0.22 \mu \mathrm{m}$ filter membrane before injection. As for the following GC-MS analysis, the PE extracts were re-dissolved with n-hexane, and then filtered through a $0.22 \mu \mathrm{m}$ filter membrane before injection.

\subsection{Insecticidal Bioassay}

\subsubsection{Insecticidal Activity on Forest Pest $O$. Formosanus}

The termite-resistance activity of tung meal against $O$. formosanus was determined by contact with filter paper containing samples with different concentrations. Briefly, appropriate amounts of different extracts $(1 \mathrm{~mL})$ were evenly dropped on the qualitative filter paper $(9 \mathrm{~cm}$ in diameter) and spread in a $9 \mathrm{~cm}$ diameter glass petri dish. Twenty worker termites of about the same size were put into each plate under $25 \pm 1{ }^{\circ} \mathrm{C}$ and $70 \pm 5 \% \mathrm{RH}$ in the dark. Deaths of worker termites were recorded and eliminated every $24 \mathrm{~h}$, and the observation was continued until all termites died. The test samples were diluted with dimethyl sulfoxide (DMSO) into the initial concentration of $10 \mathrm{mg} / \mathrm{mL}$, and then diluted with distilled water to different concentrations $(10,5,2.5,1.25,0.625 \mathrm{mg} / \mathrm{mL})$. Distilled water and DMSO solution with the same concentration were used as controls. Abbott formula (Abbott, 1925) was used for survival rate correction, and the adjusted survival rate of 6 extracts after 24,48 , and $72 \mathrm{~h}$ were calculated, respectively.

\subsubsection{Insecticidal Activity on Agricultural Pest P. xylostella}

The insecticidal activity of tung meal against $P$. xylostella was measured by feeding a diet containing extracts with different concentrations. Twenty-four $P$. xylostella in the second instar larvae were used as test samples; the larvae of $P$. xylostella were fed with different formulated feed ( $1 \mathrm{mg}$ sample $/ 1 \mathrm{~g}$ normal feed) after starvation treatment for $6 \mathrm{~h}$, and the deaths were counted and recorded every $24 \mathrm{~h}$. The formulated feed was prepared as follows: tung meal extracts $(0.005 \mathrm{~g})$ were firstly dissolved in the solvents of $100 \mu \mathrm{L}$ DMSO and $150 \mu \mathrm{L} \mathrm{H}_{2} \mathrm{O}$; then the above solutions were mixed and stirred with $10 \mathrm{~g}$ of normal feed; finally, the prepared formulated feed was air-dried and stored at $4{ }^{\circ} \mathrm{C}$. Distilled water and DMSO solution with the same concentration were used as controls. The analytical methods conducted were as the same as described in Section 2.3.1.

\subsection{Chemical Composition Analysis}

\subsubsection{UPLC-Q/TOF-MS Analysis of EA Extracts}

The chemical constituents of the EA extracts from tung meal were analyzed using an Agilent 1290 LC coupled with an Agilent 6530 accurate mass time-of-flight mass spectrometer (Agilent, Santa Clara, CA, USA) equipped with an Acquity UPLC-BEH-C18 column $(2.1 \times 50 \mathrm{~mm}, 1.7 \mu \mathrm{m}$; Waters, Milford, MA, USA). The Q/TOF-MS instrument was equipped with a dual ESI source in the negative ionization mode. The mobile phase consisted of mobile phase A $(0.1 \%$ formic acid in ultrapure water) and mobile phase B 
(acetonitrile). The LC gradient elution was as follows: 5-27\% B, 0-29 min; 27-32\% B, 29-35 $\mathrm{min} ; 32-95 \%$ B, 35-45 min; 95\% B, 45-50 min. The injection volume was $10 \mu \mathrm{L}$, and the flow rate was $0.2 \mathrm{~mL} / \mathrm{min}$. The MS was performed under the following conditions: Mass Hunter workstation (Agilent) was used to obtain profile data with a mass range of $\mathrm{m} / \mathrm{z} 100-1100$ at a rate of 1 spectra/s. The temperature and the gas flow rate of drying gas were set at $350{ }^{\circ} \mathrm{C}$ and $8 \mathrm{~L} / \mathrm{min}$, respectively. The nebulizer pressure was set at 35 psi. The capillary voltage (Vcap) and fragment voltage were set at $3500 \mathrm{~V}$ and $175 \mathrm{~V}$. The fixed collision energies were 10, 20, and $40 \mathrm{~V}$, and reference masses of $\mathrm{m} / \mathrm{z} 112.9855$ and 1033.9881 were continuously introduced for accurate mass calibration. Compounds in the extracts of tung meal were tentatively identified by comparing the parent ion, retention time, and mass fragments with the correlated references and database.

\subsubsection{GC-MS Analysis of PE Extracts}

The identification of compounds in PE extracts was carried out in accord with the previous methods with slight modification $[19,20]$. Identification was performed by the gas chromatographic system (Agilent 7890A, Agilent, Santa Clara, CA., USA) combined with MS system (Agilent 7000C, Agilent, Santa Clara, CA., USA) equipped with an HP-5 capillary column. Gas chromatography is mainly used for the separation of volatiles. The carrier gas is helium with a flow rate of $1 \mathrm{~mL} / \mathrm{min}$. The GC column temperature program was initially set at $100{ }^{\circ} \mathrm{C}$ for $8 \mathrm{~min}$ and gradually increased to $220^{\circ} \mathrm{C}$ at $5^{\circ} \mathrm{C} / \mathrm{min}$, then at $2{ }^{\circ} \mathrm{C} / \mathrm{min}$ and gradually increased to $275^{\circ} \mathrm{C}$, and finally at $5{ }^{\circ} \mathrm{C} / \mathrm{min}$ and gradually increased to $310^{\circ} \mathrm{C}$ and maintained for $10 \mathrm{~min}$. The electron ionization (EI) system was used to obtain the mass spectrum with a mass range of 25-500 Da; the ionization energy is $70 \mathrm{eV}$ in GC-MS detection. Identification of chemical composition was performed by using the NIST 11 Mass Spectral Library. The relative percentages of each compound were calculated by computerized integrator using total ion chromatography.

\subsection{Statistical Analysis}

All statistical analysis was performed employing SPSS Statistics version 24.0 software (IBM Corporation, Armonk, NY., USA), and experimental results were expressed as mean value (obtained by three replicates) \pm standard deviation. Statistical differences between groups were analyzed by one-way analysis of variance (ANOVA) combined with Duncan's test $(p<0.05)$.

\section{Results and Discussion}

\subsection{Insecticidal Activity of Tung Meal on Forest Pest O. Formosanus}

The insecticidal activity of tung meal against $O$. formosanus was represented by the survival rate after $72 \mathrm{~h}$ of treatment. It can be seen from Table S1 and Figure S1 that the insecticidal activity of tung meal varied with the types of extracts, exposure time, and concentration.

Within the concentration range of 2.5 to $10 \mathrm{mg} / \mathrm{mL}$, different tung meal extracts showed diverse degrees of insecticidal activities against $O$. formosanus, among which the EA extracts were superior to the others. The detailed results are shown in Table S1. When the concentration was $10 \mathrm{mg} / \mathrm{mL}$, the above 6 different tung meal extracts displayed comparable insecticidal activities against $O$. formosanus, with the equivalent survival rate of $0 \%$ after treatment for $72 \mathrm{~h}$; when the concentration was cut to $5 \mathrm{mg} / \mathrm{mL}$, the survival rates of the EA and PE extracts remained at $0 \%$, while the $\mathrm{DCM}, \mathrm{CE}, \mathrm{n}-\mathrm{Bu}$, and $\mathrm{H}_{2} \mathrm{O}$ extracts were $1.25 \%, 3.75 \%, 3.75 \%$, and $13.75 \%$, respectively; when the concentration came to $2.5 \mathrm{mg} / \mathrm{mL}$, the survival rate of the EA extracts also remained the lowest at $23.75 \%$, and the other groups were $41.25 \%$ (DCM), 47.5\% (CE), 56.25\% (n-Bu), 25\% $\left(\mathrm{H}_{2} \mathrm{O}\right)$, and $85 \%$ (PE). All extracts, except the PE extracts, were significantly lower $(p<0.05)$ than that of distilled water (97.50\%) and the DMSO control group (97.50\%) after $72 \mathrm{~h}$ of treatment with $2.5 \mathrm{mg} / \mathrm{mL}$ of samples. When the concentration was lower than $1.25 \mathrm{mg} / \mathrm{mL}$, the survival rate of different extracts and fractions was more than $95 \%$, indicating that the effective 
concentration of tung meal extracts and fractions against $O$. formosanus should be higher than $1.25 \mathrm{mg} / \mathrm{mL}$.

From these results, it can be concluded that tung meal has remarkable toxic activity against $O$. formosanus. Meanwhile, the EA extracts were the most promising as an insecticide, and the active components are mainly some compounds with moderate polarity. Interestingly, our present results were similar to the previous study of Sillma [21], in which they evaluated the insecticidal effects of different extracts from Jatropha curcas, another common plant of Euphorbiaceae, on two insect larvae of Bactrocera zonata and Bactrocera cucurbitae. They found that J. curcas exerted significant insecticidal effects on the two larvae, among which EA extracts were the most active part.

\subsection{Insecticidal Activity of Tung Meal on Agricultural Pest P. xylostella}

The influence of different extracts obtained from $V$. fordii on the survival rate of P. xylostella is shown in Table 1. Among all the extracts, PE extracts showed the most significant toxic activity against $P$. xylostella with a survival rate of $58.33 \%$ after adding 1 $\mathrm{mg}$ of the active ingredients into $1 \mathrm{~g}$ of normal feed for $72 \mathrm{~h}$, whereas the n-Bu extracts $(60.42 \%)$ displayed the second-highest response. EA and CE extracts led to similar survival rates of $75.00 \%$. The survival rate for the above four extracts was significantly lower than that of DMSO and water control $(P<0.05)$; the survival rates for the other two extracts were $79.17 \%\left(\mathrm{H}_{2} \mathrm{O}\right)$ and $85.42 \%(\mathrm{DCM})$.

Table 1. Insecticidal activity of different tung meal extracts on O. formosanus and P. xylostella.

\begin{tabular}{ccc}
\hline & \multicolumn{2}{c}{ Survival Rate } \\
\cline { 2 - 3 } Extracts & O. formosanus & P. xylostella \\
\hline DMSO & $97.50 \pm 2.50 \mathrm{a}$ & $97.92 \pm 2.08 \mathrm{a}$ \\
Control & $97.50 \pm 4.33 \mathrm{a}$ & $95.83 \pm 4.17 \mathrm{a}$ \\
$\mathrm{CE}$ & $47.5 \pm 16.01 \mathrm{~b}$ & $75.00 \pm 8.33 \mathrm{bcd}$ \\
PE & $85 \pm 8.66 \mathrm{a}$ & $58.33 \pm 8.33 \mathrm{~d}$ \\
$\mathrm{DCM}$ & $41.25 \pm 20.73 \mathrm{bc}$ & $85.42 \pm 2.08 \mathrm{ab}$ \\
$\mathrm{EA}$ & $23.75 \pm 10.23 \mathrm{c}$ & $75.00 \pm 4.17 \mathrm{bcd}$ \\
$\mathrm{n}-\mathrm{Bu}$ & $56.25 \pm 12.44 \mathrm{~b}$ & $60.42 \pm 6.25 \mathrm{~cd}$ \\
$\mathrm{H}_{2} \mathrm{O}$ & $25 \pm 9.35 \mathrm{c}$ & $79.17 \pm 4.17 \mathrm{abc}$ \\
\hline
\end{tabular}

The different letters (a-d) after the mean value represent significant differences at $p<0.05$ level according to Duncan's test.

In this study, PE extracts of tung meal presented the highest insecticidal effect on $P$. xylostella, indicating that the components with toxic activity to P. xylostella were mainly low-polarity compounds, and the PE extracts of tung meal were more suitable to be further developed as plant-derived insecticides against $P$. xylostella. Therefore, further analysis of the chemical components of PE extracts was later conducted to reveal the potentially responsible compounds that might play a role in the insecticidal activity of tung meal and to explore the potential of tung meal as a botanical insecticide.

\subsection{Characterization of Chemical Components in EA Extracts by UPLC-Q/TOF-MS}

In natural ecosystems, a wide variety of secondary compounds are involved in plant defenses against insects, such as insect repellents and toxins. Our study revealed the insecticidal activity of tung meal extracts against $O$. formosanus and P. xylostella. However, the complex chemical components in the tung meal extracts with very low content make them very difficult to be identified using the traditional methods often involving tedious isolation, purification, and NMR identification which greatly limit the exploration of their chemical components. UPLC-Q/TOF-MS has become an effective method for the identification of complex natural products combining its rapid and efficient separation ability of UPLC with the highly sensitive and accurate detection capacity of TOF-MS. In this study, UPLC-Q/TOF-MS was used to rapidly identify the chemical constituents in the 
EA extracts of tung meal which exhibited the best activity against $O$. formosanus as shown in Table 1.

A total of 20 compounds were tentatively identified from the EA extracts of tung meal by comparing their retention times and MS fragments with the data in the references. Each compound was numbered according to the retention time of the base peak chromatography (BPC) (Figure 1). The retention times, molecular formula and weight, and MS fragments of all compounds are listed in Table 2.

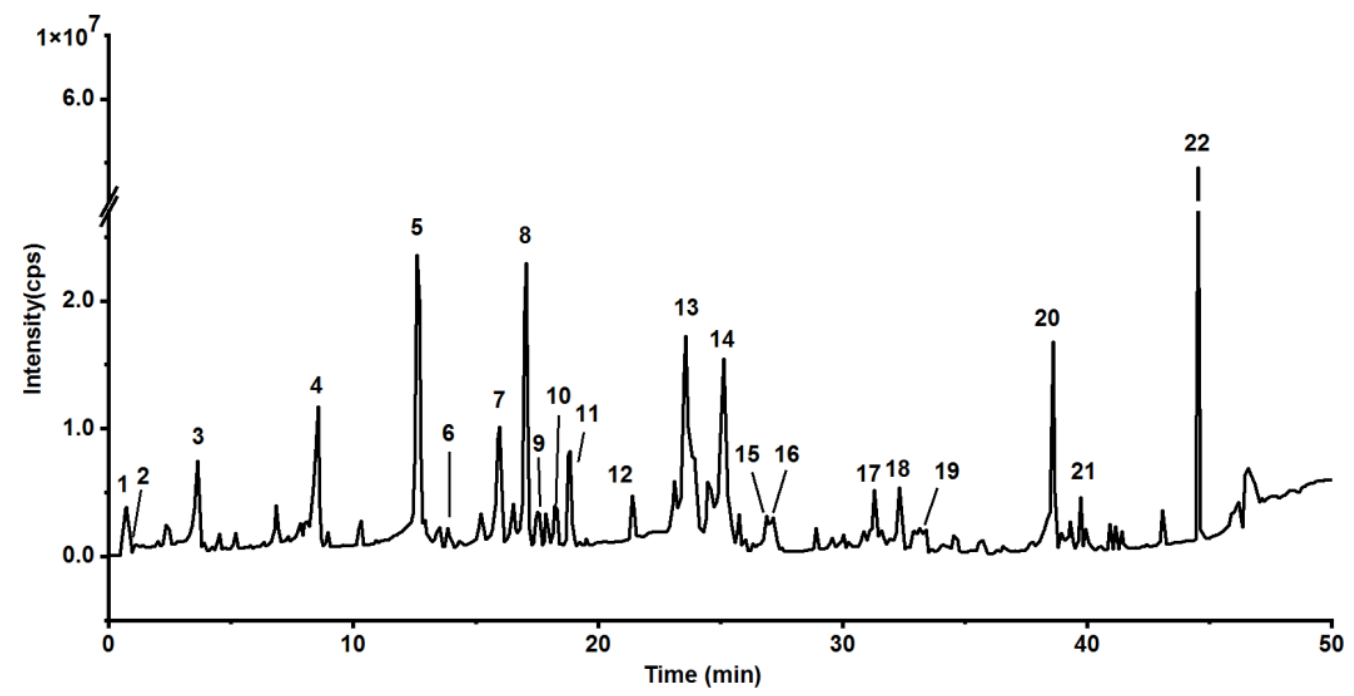

Figure 1. The base peak chromatogram (BPC) of EA extracts from tung meal. 
Table 2. Compounds tentatively identified from EA extracts of tung meal by UPLC-Q/TOF-MS.

\begin{tabular}{|c|c|c|c|c|c|c|c|c|}
\hline No. & $\begin{array}{l}t_{\mathrm{R}}{ }^{\mathrm{a}} \\
(\mathrm{Min})\end{array}$ & Components & $\begin{array}{c}\text { Content } \\
(\%)\end{array}$ & Formula & $\begin{array}{c}\text { Measured Mass } \\
(\mathrm{m} / \mathrm{z})\end{array}$ & $\begin{array}{l}\text { MS1 } \\
(m / z)\end{array}$ & $\begin{array}{c}\text { MS/MS } \\
(\mathrm{m} / z)\end{array}$ & $\begin{array}{l}\text { Error } \\
(\mathrm{ppm})\end{array}$ \\
\hline 1 & 0.68 & (+)-7-Epi-sesamin-dicatechol/( \pm )-3,3'-Bisdemethylpinoresinol & 1.42 & $\mathrm{C}_{18} \mathrm{H}_{18} \mathrm{O}_{6}$ & 329.1025 & 329.1043 & $\begin{array}{c}329,299,269,165,137 \\
109\end{array}$ & 5.47 \\
\hline 2 & 0.82 & Trehalose & 0.46 & $\mathrm{C}_{12} \mathrm{H}_{22} \mathrm{O}_{11}$ & 387.1139 & 387.1168 & $341,179,161,143$ & 7.49 \\
\hline 3 & 3.65 & 2,4-dihydroxybenzaldehyde & 2.84 & $\mathrm{C}_{7} \mathrm{H}_{6} \mathrm{O}_{3}$ & 137.0239 & 137.0241 & $137,119,109,108$ & 1.46 \\
\hline 4 & 8.55 & Unknown & 5.47 & - & - & 467.1955 & $\begin{array}{l}467,403,343,331,313 \\
233,203,185\end{array}$ & - \\
\hline 5 & 12.59 & (+)-7-Epi-sesamin-dicatechol/( \pm )-3,3'-Bisdemethylpinoresinol & 12.16 & $\mathrm{C}_{18} \mathrm{H}_{18} \mathrm{O}_{6}$ & 329.1025 & 329.1048 & $\begin{array}{c}329,269,189,165,137 \\
109\end{array}$ & 6.99 \\
\hline 6 & 13.84 & Isoamericanol B1 or related isomers (B2/C1/C2/(iso)princepin) & 0.54 & $\mathrm{C}_{27} \mathrm{H}_{26} \mathrm{O}_{9}$ & 493.1499 & 493.1513 & $\begin{array}{c}493,475,463,329,327 \\
281,165,163\end{array}$ & 2.84 \\
\hline 7 & 15.98 & Azelaic acid & 4.38 & $\mathrm{C}_{9} \mathrm{H}_{16} \mathrm{O}_{4}$ & 187.0979 & 187.0987 & $187,169,143,125$ & 4.28 \\
\hline 8 & 17.06 & (iso)americanol A & 7.51 & $\mathrm{C}_{18} \mathrm{H}_{18} \mathrm{O}_{6}$ & 659.2129 & 659.2154 & $\begin{array}{l}329,311,299,165,147 \\
135\end{array}$ & 3.79 \\
\hline 9 & 17.53 & 5,7,4'-Tri-O-methylcatechin & 1.13 & $\mathrm{C}_{18} \mathrm{H}_{20} \mathrm{O}_{6}$ & 663.2442 & 663.2473 & $\begin{array}{l}332,331,313,301,165 \\
147,135\end{array}$ & 4.68 \\
\hline 10 & 18.23 & Isoamericanol B1 or related isomers (B2/C1/C2/(iso)princepin) & 1.10 & $\mathrm{C}_{27} \mathrm{H}_{26} \mathrm{O}_{9}$ & 493.1499 & 493.1534 & $\begin{array}{c}493,463,329,327,299 \\
269,165,163,137\end{array}$ & 7.10 \\
\hline 11 & 18.86 & (iso)americanol A & 2.63 & $\mathrm{C}_{18} \mathrm{H}_{18} \mathrm{O}_{6}$ & 659.2129 & 659.2176 & $\begin{array}{c}329,311,299,165,147 \\
135\end{array}$ & 7.13 \\
\hline 12 & 21.39 & Isoamericanin A & 0.93 & $\mathrm{C}_{18} \mathrm{H}_{16} \mathrm{O}_{6}$ & 327.0869 & 327.0890 & $\begin{array}{c}327,297,165,163,147 \\
135\end{array}$ & 6.42 \\
\hline 13 & 23.59 & Isoamericanol B1 or related isomers (B2/C1/C2/(iso)princepin) & 11.87 & $\mathrm{C}_{27} \mathrm{H}_{26} \mathrm{O}_{9}$ & 493.1499 & 493.1528 & $\begin{array}{c}493,475,463,329,327 \\
165,163,137\end{array}$ & 5.88 \\
\hline 14 & 25.14 & Isoamericanol $\mathrm{B} 1$ or related isomers (B2/C1/C2/(iso)princepin) & 8.67 & $\mathrm{C}_{27} \mathrm{H}_{26} \mathrm{O}_{9}$ & 493.1499 & 493.1509 & $\begin{array}{c}493,463,329,327,165 \\
163\end{array}$ & 2.03 \\
\hline 15 & 26.88 & Isoamericanol B1 or related isomers (B2/C1/C2/(iso)princepin) & 0.69 & $\mathrm{C}_{27} \mathrm{H}_{26} \mathrm{O}_{9}$ & 493.1499 & 493.1518 & $493,329,327,165,163$ & 3.85 \\
\hline 16 & 27.17 & Isoamericanol $\mathrm{B} 1$ or related isomers (B2/C1/C2/(iso)princepin) & 1.14 & $\mathrm{C}_{27} \mathrm{H}_{26} \mathrm{O}_{10}$ & 493.1499 & 493.1512 & $\begin{array}{l}493,477,465,329,327 \\
299,165,163,147,135\end{array}$ & 2.64 \\
\hline 17 & 31.28 & Isodiverniciasin $\mathrm{A}$ /diverniciasin $\mathrm{B} /$ diverniciasin $\mathrm{C}$ & 2.70 & $\mathrm{C}_{36} \mathrm{H}_{34} \mathrm{O}_{13}$ & 657.1972 & 657.2005 & $\begin{array}{c}657,493,461,329,327 \\
165,163\end{array}$ & 5.02 \\
\hline 18 & 32.31 & Isodiverniciasin $\mathrm{A}$ /diverniciasin $\mathrm{B} /$ diverniciasin $\mathrm{C}$ & 2.25 & $\mathrm{C}_{36} \mathrm{H}_{34} \mathrm{O}_{13}$ & 657.1972 & 657.2018 & $\begin{array}{c}657,493,461,329,327 \\
165,163\end{array}$ & 7.00 \\
\hline 19 & 33.40 & Isodiverniciasin $\mathrm{A}$ /diverniciasin $\mathrm{B} /$ diverniciasin $\mathrm{C}$ & 1.28 & $\mathrm{C}_{36} \mathrm{H}_{34} \mathrm{O}_{13}$ & 657.1972 & 657.1973 & $\begin{array}{l}657,493,461,329,327 \\
166,163\end{array}$ & 0.15 \\
\hline 20 & 38.60 & (9S,10E,12Z,15Z)-9-Hydroperoxyoctadeca-10,12,15-Trienoic acid & 4.25 & $\mathrm{C}_{18} \mathrm{H}_{30} \mathrm{O}_{4}$ & 309.2066 & 309.2093 & $309,291,225,209,185$ & 8.74 \\
\hline 21 & 39.73 & Corchorifatty acid D & 0.84 & $\mathrm{C}_{18} \mathrm{H}_{28} \mathrm{O}_{4}$ & 307.1910 & 307.1930 & $\begin{array}{c}307,289,265,223,185 \\
137\end{array}$ & 6.51 \\
\hline 22 & 44.54 & Unknown & 10.25 & - & 339.2374 & - & $339,183,163,147$ & - \\
\hline
\end{tabular}

${ }^{\mathrm{a}}$ Retention time according to the base peak chromatogram in Figure $1 .{ }^{\mathrm{b}}$ The relative content (\%) was obtained by integrating the chromatogram peaks in Figure 1. 


\subsubsection{Lignans}

Lignans are common components of Euphorbiaceae plants. As illustrated in Table 2, fourteen peaks (peaks 1, 5, 6, 8, 10,11,12,13,14,15, 16, 17, 18, and 19) were tentatively identified and classified as lignans. Compounds 8 and 11 exhibited a similar parent molecular ion $[2 \mathrm{M}-\mathrm{H}]^{-}$at $\mathrm{m} / z 659\left(\mathrm{t}_{\mathrm{R}} 17.06 \mathrm{~min}\right.$ and $\left.18.86 \mathrm{~min}\right)$ and MS fragments. The deprotonated molecular ion $[\mathrm{M}-\mathrm{H}]^{-}$was shown at $\mathrm{m} / z$ 329. A characteristic ion can be seen at $m / z 165$ due to the Retro Diels-Alder (RDA) cleavage, and the fragment ions at $m / z 147$ and $m / z 137$ could be attributed to the continuous loss of $\mathrm{H}_{2} \mathrm{O}$ and $\mathrm{CO}$. The fragment ion at $\mathrm{m} / \mathrm{z} 163$ was due to the cleavage of 1,4-dioxane, and the additional loss of $\mathrm{CH}_{2} \mathrm{O}$ yielded fragments at $m / z 135$. Figure 2 shows the MS spectrum and the corresponding proposed fragment pathways. Hence, peaks 8 and 11 were tentatively assigned as americanol A and isoamericanol $\mathrm{A}$, which is in good agreement with the previous report [23].

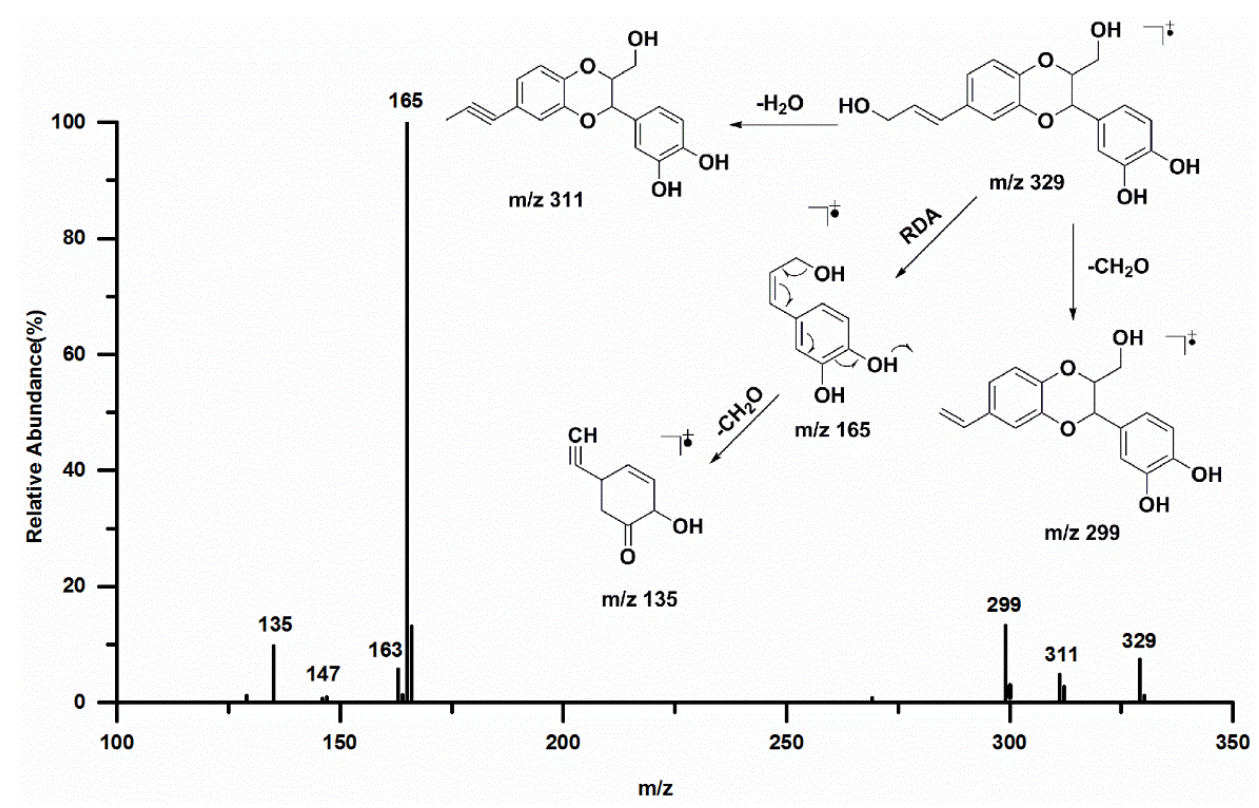

Figure 2. The fragmentation pathways based on the MS/MS spectra of isoamericanol A.

Compounds 1 and 5 were detected at $t_{R} 0.68$ and 12.59 min with similar deprotonated molecular ion $[\mathrm{M}-\mathrm{H}]^{-}$of $m / z 329$ and MS spectral data, which indicated that they were the isomers. Two distinguished fragments at $\mathrm{m} / \mathrm{z} 329$ and $\mathrm{m} / \mathrm{z} 137$ were generated by deprotonation or the cleavage of the furan ring. The fragment ions at $\mathrm{m} / \mathrm{z} 299$ and $\mathrm{m} / \mathrm{z}$ 269 indicated the continuous release of the $\mathrm{CH}_{2} \mathrm{O}$ group from $[\mathrm{M}-\mathrm{H}]^{-}$and $\left[\mathrm{M}-\mathrm{H}-\mathrm{CH}_{2} \mathrm{O}\right]^{-}$. A characteristic ion can be seen at $m / z 165$ due to the RDA cleavage. The MS data were in agreement with those previously reported, and compounds 1 and 5 were identified as (+)-7-epi-sesamin-dicatechol and ( \pm )-3,3'-bisdemethylpinoresinol, respectively [22,23].

Compound 12 displayed a deprotonated molecular ion $[\mathrm{M}-\mathrm{H}]^{-}$of $\mathrm{m} / z 327$ at $\mathrm{t}_{\mathrm{R}}$ $21.39 \mathrm{~min}$, which was $2 \mathrm{Da}$ (2 hydrogens) less than americanol A and isoamericanol A. The fragment at $m / z 297$ was attributed to the neutral loss of $\mathrm{CH}_{2} \mathrm{O}$. Typical fragment ions of compound 12 were obtained at $m / z$ 165, $m / z 163, m / z 147$, and $m / z$ 135, which were similar to americanol A and isoamericanol A. Compound 12 was identified as isoamericanin A, where one hydroxymethyl group in isoamericanol A was oxidized to an aldehyde group, in comparison with their spectral features. This compound had also been found in the seed testa of Vernicia fordii [23].

There are six neolignan isomers including peaks $6,10,13,14,15$, and 16 , which were detected at $t_{\mathrm{R}} 13.84,18.23,23.59,25.14,26.88$, and $27.17 \mathrm{~min}$, respectively. The deprotonated molecular ion [M-H] ${ }^{-}$was observed at $\mathrm{m} / \mathrm{z} 493$. The fragment ions of $\mathrm{m} / \mathrm{z} 475$ and $\mathrm{m} / \mathrm{z} 463$ indicated the easier loss of the $\mathrm{H}_{2} \mathrm{O}$ and $\mathrm{CH}_{2} \mathrm{O}$ groups. The additional loss of $\mathrm{C}_{9} \mathrm{H}_{8} \mathrm{O}_{3}$ group yielded a fragment at $\mathrm{m} / \mathrm{z} 299$. The major fragment ions of $\mathrm{m} / \mathrm{z} 329$ and $\mathrm{m} / \mathrm{z} 163$ 
resulted from the cleavage of 1,4-dioxane. The fragment ion of $m / z 165$ was similar to americanol $\mathrm{A}$ and isoamericanol $\mathrm{A}$. By comparing the fragmentation pathways with those of the references, compounds $6,10,13,14,15$, and 16 could be tentatively identified as isoamericanol B1, isoamericanol B2, isoamericanol C1, isoamericanol C2, princepin, and isoprincepin [24], which was in accord with the findings of Chen et al [23]. Those compounds were also named sesquineolignans because they were structurally formed by the oxidative polymerization of three phenylpropyl. In addition, all of these chemical components had also been found in the seeds of Joannesia princeps Vellozo, another plant of the Euphorbiaceae [25].

Three dilignant isomers, compounds 17, 18, and 19, were detected at $t_{R} 31.28,32.31$, and $33.40 \mathrm{~min}$ with the same deprotonated molecular ion $[\mathrm{M}-\mathrm{H}]^{-}$of $m / z 657$ and MS spectral data. The characteristic fragment ions of $m / z 493$ and $m / z 163$ resulted from the cleavage of 1,4-dioxane. Another major characteristic fragment ion of $m / z 165$ was also observed. Furthermore, fragment ions of $m / z 493$ and other fragment ions were similar to those of (iso) princepin. Those three compounds were tentatively identified as isodiverniciasin A, diverniciasin $C$, and diverniciasin B, which have been detected in the seed testa of $V$. fordii [23].

\subsubsection{Fatty Acids}

Compound 7 exhibited the deprotonated molecular ion at $m / z 187[\mathrm{M}-\mathrm{H}]^{-}$at $\mathrm{t}_{\mathrm{R}}$ $15.98 \mathrm{~min}$. The fragment ions at $\mathrm{m} / \mathrm{z} 169$ and $\mathrm{m} / \mathrm{z} 143$ were obtained by the successive loss of $\mathrm{H}_{2} \mathrm{O}$ and $\mathrm{CO}_{2}$ groups, respectively. The major fragment ion at $m / z 125$ was obtained by the further loss of $\mathrm{C}_{2} \mathrm{H}_{4} \mathrm{O}$ from the $\left[\mathrm{M}-\mathrm{H}-\mathrm{H}_{2} \mathrm{O}\right]^{-}$. According to the literature [26] and the discussion mentioned above, compound 7 could be identified as azelaic acid. Compound 20 , which appeared at the $t_{R} 38.60 \mathrm{~min}$, exhibited a parent ion at $m / z 309$. The fragment ions at $m / z 291$ and $m / z 185$ could be attributed to the loss of $\mathrm{H}_{2} \mathrm{O}$ or $\mathrm{C}_{9} \mathrm{H}_{16}$, and fragment ion at $m / z 209$ was generated by the successive loss of $\mathrm{C}_{6} \mathrm{H}_{10}$. According to the Mass Bank Database and the discussion mentioned, compound 20 was tentatively assigned as (9S,10E,12Z,15Z)-9-hydroperoxyoctadeca-10,12,15-trienoic acid.

Compound 21 was observed at $m / z 307\left(t_{R} 39.73 \mathrm{~min}\right)$. The abundant fragment ions at $m / z 289$ and $m / z 185$ could be attributed to the loss of $\mathrm{H}_{2} \mathrm{O}$ or $\mathrm{C}_{8} \mathrm{H}_{10} \mathrm{O}$. The additional loss of $\mathrm{CH}_{4} \mathrm{O}_{2}$ group yielded fragment ion at $m / z$ 137. These mass spectra matched segments of the Mass Bank Database; therefore compound 21 was preliminarily designated as corchorifatty acid D.

\subsubsection{Others}

Compound 2, which appeared at the retention time of $0.82 \mathrm{~min}$, revealed a $[\mathrm{M}+\mathrm{FA}-\mathrm{H}]^{-}$ ion at $m / z$ 387. It yielded the productions at $m / z 179$ and $m / z 161$ in the MS/MS by the loss of glucose $(180 \mathrm{Da})$ or glucose residue $(162 \mathrm{Da})$. Furthermore, a smaller fragment resulting from the cleavage of the hexose ring was observed at $m / z 89\left(\mathrm{C}_{3} \mathrm{H}_{5} \mathrm{O}_{3}\right)$. According to the literature [27] and the discussion mentioned, compound 2 could be identified as trehalose. Compound 3 presented the deprotonated molecular ion $m / z 137[\mathrm{M}-\mathrm{H}]^{-}$at $\mathrm{t}_{\mathrm{R}} 3.65 \mathrm{~min}$. The distinguished fragment ion of $m / z 119$ indicated the loss of $\mathrm{H}_{2} \mathrm{O}$, and another major fragment ion $\mathrm{m} / \mathrm{z} 108$ was obtained by the loss of $\mathrm{CO}$. Considering that the above fragments were the same as in the previous report [28], compound 3 was tentatively identified as 2,4-dihydroxybenzaldehyde, which had been detected in the seed testa of $V$. fordii [23].

The electrospray mass spectrum of compound 9 exhibited a parent ion of $m / z 663$ [2M$\mathrm{H}]^{-}$at $t_{\mathrm{R}} 17.53 \mathrm{~min}$. Two characteristic fragments at $m / z 331$ and $m / z 313$ were generated by deprotonation and the loss of $\mathrm{H}_{2} \mathrm{O}$. The fragment $\left[\mathrm{M}-\mathrm{H}-\mathrm{OCH}_{3}\right]^{-}$was found at $m / z 301$. The ions at $m / z 165$ and $m / z 147$ were the typical fragments of RDA cleavage and their dehydrated fragments. These fragments were similar to the mass spectrometry fragments in the Human Metabolome Database (HMDB), and compound 9 was preliminarily identified as 5,7,4'-tri-O-methylcatechin. 
According to the structures of these compounds shown in Figure 3, these components can be structurally characterized as lignans, fatty acids, flavonoids, disaccharides, and dihydroxybenzaldehyde. According to their basic carbon frames, those lignans can be divided into three categories, including monolignan (compounds 1, 5, 8, 11, and 12), sesquineolignan (compounds 6, 10,13,14, 15, and 16), and dineolignans (compounds 17, 18 and 19). By integrating the chromatogram, it was found that the contents of isoamericanol $\mathrm{B} 1$ and its related isomers (isoamericanol B2, isoamericanol C1, isoamericanol C2, isoprincepin, and isoprincepin) were the highest in the EA extracts of tung meal, accounting for $24.01 \%$ of the total, followed by (+)-7-epi-sesamin-dicatechol and its related isomers $( \pm$ )-3,3'-bisdemethylpinoresinol, which also accounted for a high proportion of $13.58 \%$; besides, americanol A and its related isomer isoamericanol A also accounted for a high proportion of $10.14 \%$.

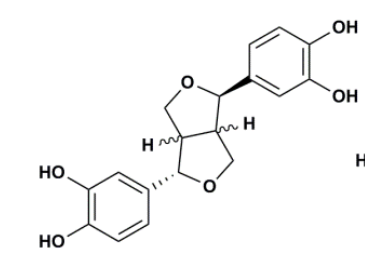

1/5: (+)-7-Epi-sesamindicatechol<smiles>OCC1OC(OC2OC(CO)C(O)C(O)C2O)C(O)C(O)C1O</smiles>

2: Trehalose

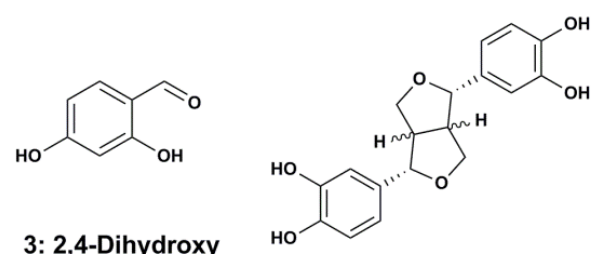
$\begin{array}{ll}\text { 3: 2,4-Dihydroxy } & \text { 1/5: ( } \pm \text { )-3,3'-Bisdemethylpinoresinol } \\ \text { benzaldehyde }\end{array}$<smiles>CCC=Cc1ccc2c(c1)O[C@H](c1ccc3c(c1)O[C@H](c1ccc(O)c(O)c1)[C@H](CO)O3)[C@H](CO)O2</smiles>

6/10/13/14/15/16: Isoamericanol B1/B2

HO<smiles>CCc1ccc2c(c1)O[C@H](CO)[C@@H](c1ccc(O)c(O)c1)O2</smiles>

6/10/13/14/15/16: Isoamericanol C1/C2<smiles>OC[C@H]1Oc2ccc([C@@H]3OC[C@H]4[C@H](c5ccc(O)c(O)c5)OC[C@@H]43)cc2O[C@H]1c1ccc(O)c(O)c1</smiles>

6/10/13/14/15/16:Isoprincepin<smiles>OC/C=C/c1ccc2c(c1)OC(CO)C(c1ccc(O)c(O)c1)O2</smiles>

8/11: Americanol A

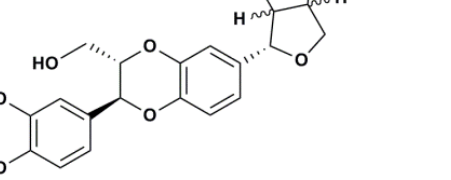

6/10/13/14/15/16: Princepin

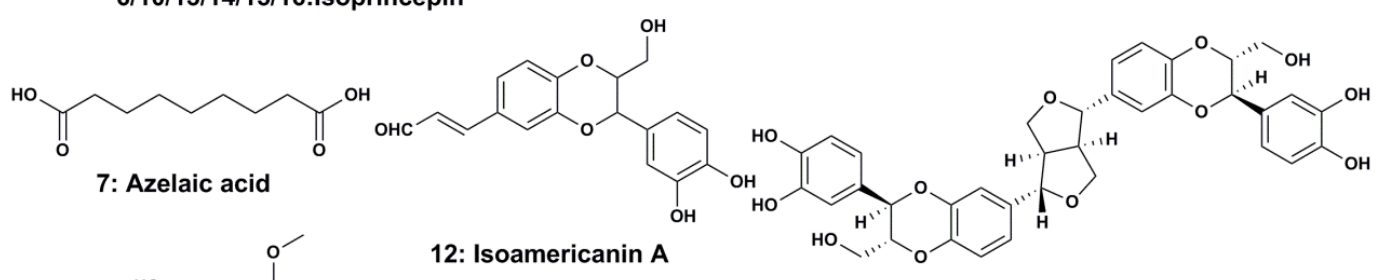<smiles>COc1ccc(C2Oc3cc(OC)cc(OC)c3C[C@H](O)[C@H]2C(C)C)c(O)c1</smiles>

12: Isoamericanin A

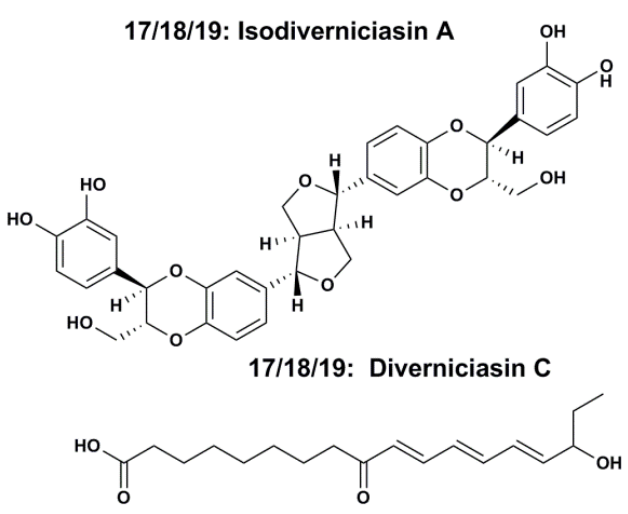

21: Corchorifatty acid D

20: (9S,10E,12Z,15Z)-9-Hydroperoxy10,12,15-octadecatrienoic acid

Figure 3. The structures of compounds identified from EA extracts of tung meal by UPLC-Q/TOF-MS. 
Previous studies revealed that trehalose can remarkably reduce the mean day survival rate of sweet potato whitefly Bemisia tabaci (Gennadius) [29], and trehalose/mannose/maltose specific lectins exhibited promising insecticidal activities against stored product pests [30]. Azelaic acid was also detected at the active sites of a variety of plants with remarkable insecticidal activities [31]. The insecticidal activity of lignans has been rarely studied or not yet discovered. Some lignans, such as ( \pm )-3,3'-bisdemethylpinoresinol, americanol A, americanin A, and isoprincepin, have been found in the fruit of Morinda citrifolia [32], and the fruit extracts of Morinda citrifolia have been reported to exert significant insecticidal activities against a variety of agricultural pests and have been used as an effective insecticide in the Philippines and Hawaii [33]. Princepin and isoprincepin are uncommon in natural products and their insecticidal activities have been poorly studied, but their structure-related compound haedoxan A has been reported to have prominent insecticidal activity $[34,35]$. Furthermore, J. curcas has been reported to have insecticidal activities on houseflies and insect pests of stored products [36,37]. In this study, we detected some major components in tung meal, such as isoamericanol A, americanol A, (+)-7-Epi-sesamindicatechol, $( \pm)-3,3^{\prime}$-Bisdemethylpinoresinol, and isoprincepin, which are also the main components of $J$. curcas [38]. In conclusion, the insecticidal activity of tung meal could be attributed to the presence of those components; however, the insecticidal activities and their mechanisms based on these potential components need to be further verified.

\subsection{Identification of Volatile Constituents in PE Extracts by GC-MS}

The components in PE extracts were tentatively identified by comparing the MS fragments with the NIST database. Based on the literature, a compound whose similarity scores above $90 \%$ was taken into account [39]. The gas chromatograms of PE extracts and the corresponding compounds tentatively identified in the extracts, along with the retention times and percentages are shown in Figure 4 and Table 3, respectively. According to the retention times peaked in the GC-MS analysis, a total of twenty-nine compounds, accounting for $87.26 \%$, were identified, which mainly consisted of unsaturated fatty acids and their ethyl ester, phytosterols, etc.

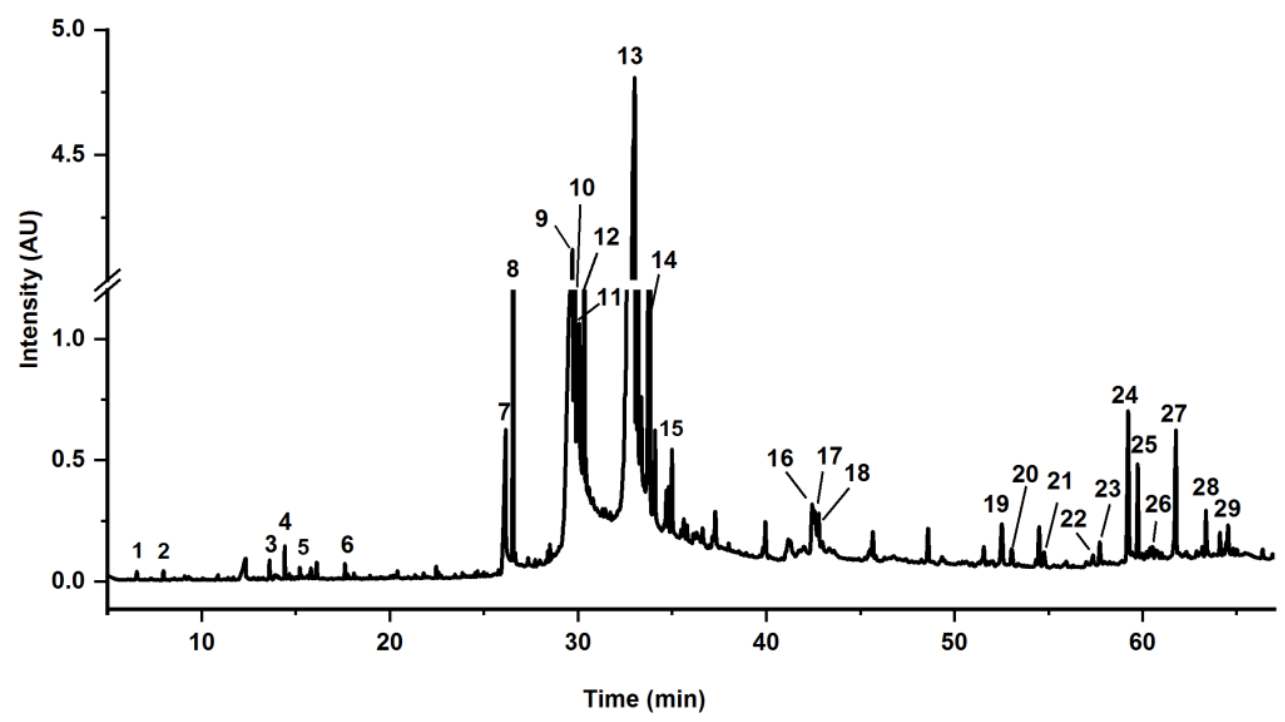

Figure 4. The GC-MS chromatogram of PE extracts from tung meal. 
Table 3. Compounds estimated from PE extracts of tung meal by GC-MS.

\begin{tabular}{|c|c|c|c|c|c|}
\hline No. & $\begin{array}{c}t_{R}{ }^{a} \\
(\min )\end{array}$ & $\begin{array}{c}\text { Content } \\
(\%)\end{array}$ & Components ${ }^{b}$ & Formula & $\mathrm{SC}^{\mathrm{c}}$ \\
\hline 1 & 6.56 & 0.06 & Octanoic acid & $\mathrm{C}_{8} \mathrm{H}_{16} \mathrm{O}_{2}$ & 93 \\
\hline 2 & 7.97 & 0.04 & 2,4-Decadienal & $\mathrm{C}_{10} \mathrm{H}_{16} \mathrm{O}$ & 91 \\
\hline 3 & 13.61 & 0.11 & Caryophyllene & $\mathrm{C}_{15} \mathrm{H}_{24}$ & 99 \\
\hline 4 & 14.42 & 0.14 & (-)- $\alpha$-Gurjunene & $\mathrm{C}_{15} \mathrm{H}_{24}$ & 91 \\
\hline 5 & 15.21 & 0.08 & $\beta$-Copaene & $\mathrm{C}_{15} \mathrm{H}_{24}$ & 93 \\
\hline 6 & 17.62 & 0.07 & (-)-Spathulenol & $\mathrm{C}_{15} \mathrm{H}_{24} \mathrm{O}$ & 90 \\
\hline 7 & 26.15 & 2.09 & Palmitic acid & $\mathrm{C}_{16} \mathrm{H}_{32} \mathrm{O}_{2}$ & 93 \\
\hline 8 & 26.56 & 3.82 & Ethyl palmitate & $\mathrm{C}_{18} \mathrm{H}_{36} \mathrm{O}_{2}$ & 99 \\
\hline 9 & 29.69 & 14.36 & Ethyl linolate & $\mathrm{C}_{20} \mathrm{H}_{36} \mathrm{O}_{2}$ & 99 \\
\hline 10 & 29.83 & 6.34 & Ethyl oleate & $\mathrm{C}_{20} \mathrm{H}_{38} \mathrm{O}_{2}$ & 97 \\
\hline 11 & 30.06 & 2.38 & Stearic acid & $\mathrm{C}_{18} \mathrm{H}_{36} \mathrm{O}_{2}$ & 99 \\
\hline 12 & 30.33 & 3.09 & Ethyl stearate & $\mathrm{C}_{20} \mathrm{H}_{40} \mathrm{O}_{2}$ & 99 \\
\hline 13 & 33.00 & 38.44 & Ethyl $\alpha$-linolenateor Ethyl $\gamma$-linolenate & $\mathrm{C}_{20} \mathrm{H}_{34} \mathrm{O}_{2}$ & 98 \\
\hline 14 & 33.82 & 8.93 & Ethyl $\alpha$-linolenate or Ethyl $\gamma$-linolenate & $\mathrm{C}_{20} \mathrm{H}_{34} \mathrm{O}_{2}$ & 98 \\
\hline 15 & 34.99 & 0.7 & 2,2'-Methylenebis(4-methyl-6-tert-butylphenol) & $\mathrm{C}_{23} \mathrm{H}_{32} \mathrm{O}_{2}$ & 94 \\
\hline 16 & 42.44 & 0.69 & 2-Linoleoylglycerol & $\mathrm{C}_{21} \mathrm{H}_{38} \mathrm{O}_{4}$ & 90 \\
\hline 17 & 42.57 & 0.48 & 2-Monoolein & $\mathrm{C}_{21} \mathrm{H}_{40} \mathrm{O}_{4}$ & 97 \\
\hline 18 & 42.78 & 0.31 & Heptacosane & $\mathrm{C}_{27} \mathrm{H}_{56}$ & 91 \\
\hline 19 & 52.52 & 0.58 & $\gamma$-Tocopherol & $\mathrm{C}_{28} \mathrm{H}_{48} \mathrm{O}_{2}$ & 99 \\
\hline 20 & 53.04 & 0.25 & Stigmasta-3,5-diene & $\mathrm{C}_{29} \mathrm{H}_{48}$ & 95 \\
\hline 21 & 54.75 & 0.18 & Vitamin E & $\mathrm{C}_{29} \mathrm{H}_{50} \mathrm{O}_{2}$ & 99 \\
\hline 22 & 57.36 & 0.14 & Dotriacontane & $\mathrm{C}_{32} \mathrm{H}_{6} \mathrm{O}_{6}$ & 96 \\
\hline 23 & 57.72 & 0.23 & Stigmasterol & $\mathrm{C}_{29} \mathrm{H}_{48} \mathrm{O}$ & 99 \\
\hline 24 & 59.23 & 1.58 & $\beta$-Sitosterol & $\mathrm{C}_{29} \mathrm{H}_{50} \mathrm{O}$ & 92 \\
\hline 25 & 59.74 & 0.73 & Tritriacontane & $\mathrm{C}_{33} \mathrm{H}_{68}$ & 99 \\
\hline 26 & 60.52 & 0.09 & 4,22-stigmastadiene-3-one & $\mathrm{C}_{29} \mathrm{H}_{46} \mathrm{O}$ & 96 \\
\hline 27 & 61.76 & 0.96 & Stigmast-4-en-3-one & $\mathrm{C}_{29} \mathrm{H}_{48} \mathrm{O}$ & 98 \\
\hline 28 & 63.36 & 0.34 & Pentatriacontane & $\mathrm{C}_{35} \mathrm{H}_{72}$ & 97 \\
\hline 29 & 64.53 & 0.36 & Stigmastane-3,6-dione & $\mathrm{C}_{29} \mathrm{H}_{48} \mathrm{O}_{2}$ & 91 \\
\hline
\end{tabular}

${ }^{a}$ Retention time according to the GC-MS chromatogram in Figure $4 .{ }^{\mathrm{b}}$ The relative content (\%) was obtained by integrating the chromatogram peaks in Figure $4 .{ }^{\mathrm{c}}$ Molecular weight; ${ }^{\mathrm{d}}$ Similarity score obtained by matching NIST 11.

Among those compounds, the highest peak appeared at $t_{\mathrm{R}} 33.00 \mathrm{~min}$, accounting for $38.44 \%$ of the total content, which was estimated as ethyl $\alpha$-linolenate or ethyl $\gamma$-linolenate according to the MS data. The third highest peak appeared in $t_{R} 33.82$ min, accounting for $8.93 \%$ of the total content, and was tentatively identified as the isomer of the highest peak due to the same MS/MS fragments. The second highest peak appeared in $t_{R} 29.69 \mathrm{~min}$, accounting for $14.36 \%$ of the total content, and was tentatively identified as ethyl linolate. In addition, ethyl oleate $(6.34 \%)$, ethyl palmitate $(3.82 \%)$, ethyl stearate $(3.09 \%)$, stearic acid $(2.38 \%)$, palmitic acid $(2.09 \%)$, and $\beta$-sitosterol $(1.58 \%)$ were also tentatively identified in PE extracts. These results were consistent with previous studies $[40,41]$.

Fatty acids and their ethyl ester, and $\beta$-sitosterol may be the principal components exerting remarkable insecticidal activity against $P$. xyloides. For example, ethyl linolenate, ethyl oleate, ethyl palmitate, ethyl stearate, and ethyl linolate were found in Eupatorium odoratum extract, an insect repellent, by inhibiting oviposition of $P$. xyloides [42]. The volatile oils and crude extracts of Zingiber officinale have noteworthy insecticidal, repellent, and oviposition activities against many pests like Callosobruchus chinensis, Sitophilus zeamais, and P. xylostella [43]. In a similar study, five components with a content of more than $2 \%$ have also been detected in Z. officinale essential oil and oleoresins, including palmitic acid, ethyl palmitate, ethyl linolate, ethyl oleate, and stearic acid [44]. In addition, the ethanol extracts of Cynanchi auriculati showed superior insecticidal efficacy to common pesticides against $P$. xylostella, among which PE extracts was the highest, and the analysis of chemical composition showed that it was rich in $\beta$-sitosterol [45]. 


\section{Conclusions}

In the present study, different extracts from the deoiled tung meal of $V$. fordii were first revealed to exhibit diverse insecticidal activities against $O$. formosanus and P. xylostella, respectively. The corresponding active extracts and potential components, including lignans, fatty acids and their derivatives, and others, were further confirmed by UPLC-Q/TOF-MS and GC-MS, which provided strong support for alternative forest and agricultural pest control by tung meal. Our results suggest that tung meal extract or its derivatives may be used to control and manage the infestation of some pests like O. formosanus and P. xylostella, as well as to mitigate the damage caused by chemical pesticides currently in use.

Supplementary Materials: The following are available online at https:/ /www.mdpi.com/article/10 $.3390 /$ insects12050425/s1, Table S1: Insecticidal activity of different tung meal extracts on termite of O. formosanus, Figure S1: Insecticidal activity of different tung meal extracts on $O$. formosanus and $P$. xylostella. The different letters (a-c) after the mean value represent significant differences at $p<0.05$ level according to Duncan Test.

Author Contributions: Conceptualization, G.C., S.L., L.Z., and M.G.; methodology, H.Z., G.C., L.Z., and M.G.; software, H.Z.; validation, G.C., S.L., and M.G.; formal analysis, H.Z.; investigation, H.Z., G.C.; resources, S.L.; data curation, M.G.; writing—original draft preparation, H.Z.; writing-review and editing, H.Z., G.C., and M.G.; visualization, H.Z.; supervision, M.G.; project administration, S.L., L.Z., and M.G.; funding acquisition, S.L. and M.G. All authors have read and agreed to the published version of the manuscript.

Funding: This research was funded by the National Key R\&D Program of China, grant number 2017YFD0600703.

Institutional Review Board Statement: Not applicable.

Data Availability Statement: All data analyzed in this study are included in this article and supplementary materials.

Acknowledgments: We thank Guangwan Hu of Wuhan Botanical Garden of Chinese Academy of Sciences for assisting in the identification of plant materials.

Conflicts of Interest: The authors declare no conflict of interest.

\section{References}

1. Cui, P.; Lin, Q.; Fang, D.; Zhang, L.; Li, R.; Cheng, J.; Gao, F.; Shockey, J.; Hu, S.; Lü, S. Tung tree (Vernicia fordii, Hemsl.) genome and transcriptome sequencing reveals co-ordinate up-regulation of fatty acid $\beta$-oxidation and triacylglycerol biosynthesis pathways during eleostearic acid accumulation in seeds. Plant Cell Physiol. 2018, 59, 1990-2003. [CrossRef] [PubMed]

2. Liang, B.; Zhao, J.; Li, G.; Huang, Y.; Yang, Z.; Yuan, T. Facile synthesis and characterization of novel multi-functional bio-based acrylate prepolymers derived from tung oil and its application in UV-curable coatings. Ind. Crop. Prod. 2019, 138, 111585. [CrossRef]

3. Zheng, X.; Zhang, J.; Wu, F.; Qu, S. Extraction and composition characterisation of amino acids from tung meal. Nat. Prod. Res. 2016, 30, 849-852. [CrossRef]

4. Makkar, H.P.S.; Martinez-Herrera, J.; Becker, K. Variations in seed number per fruit, seed physical parameters and contents of oil, protein and phorbol ester in toxic and non-toxic genotypes of Jatropha curcas. J. Plant Sci. 2008, 3, 260-265. [CrossRef]

5. Mann, G.E.; Hoffman, W.H.; Ambrose, A.M. Oilseed processing, detoxification and toxicological studies of tung meal. J. Agric. Food Chem. 1954, 2, 258-263. [CrossRef]

6. Zan, L.; Song, W.; Liu, J.; Guo, S.; Li, H.; Wang, Y. Study on toxicity of water extract from tung meal on aboveground and underground pest. Nonwood Forest Res. 2018, 36, 75-78.

7. Roongtawan, M.; Anuluck, J.; Udom, C.; Atchariya, J.; Doungrat, R.; Anchalee, W.; Pradya, S.; Benjawan, B. Natural larvicides of botanical origin against dengue vector aedes aegypti (Diptera: Culicidae). Southeast Asian J. Trop. Med. 2018, 49, 227-239.

8. Santos, A.A.; Santos de Oliveira, B.M.; Melo, C.R.; Santana Lima, A.P.; Rabelo Santana, E.D.; Blank, A.F.; Picanco, M.C.; Araujo, A.P.A.; Cristaldo, P.F.; Bacci, L. Sub-lethal effects of essential oil of lippia sidoides on drywood termite Cryptotermes brevis (Blattodea: Termitoidea). Ecotoxicol. Environ. Saf. 2017, 145, 436-441. [CrossRef]

9. Rust, M.K.; Su, N.-Y. Managing social insects of urban importance. Annu. Rev. Entomol. 2012, 57, 355-375. [CrossRef]

10. Sarfraz, M.; Keddie, B.A. Conserving the efficacy of insecticides against Plutella xylostella (L.) (Lep., Plutellidae). J. Appl. Entomol. 2005, 129, 149-157. [CrossRef] 
11. Abro, G.H.; Syed, T.S.; Kalhoro, A.N.; Sheikh, G.H.; Awan, M.S.; Jessar, R.D.; Shelton, A.M. Insecticides for control of the diamondback moth, Plutella xylostella (L.) (Lepidoptera: Plutellidae) in pakistan and factors that affect their toxicity. Crop. Prot. 2013, 52, 91-96. [CrossRef]

12. Furlong, M.J.; Wright, D.J.; Dosdall, L.M. Diamondback moth ecology and management: Problems, progress, and prospects. Annu. Rev. Entomol. 2013, 58, 517-541. [CrossRef]

13. Sparks, T.C.; Wessels, F.J.; Lorsbach, B.A.; Nugent, B.M.; Watson, G.B. The new age of insecticide discovery-the crop protection industry and the impact of natural products. Pestic. Biochem. Phys. 2019, 161, 12-22. [CrossRef] [PubMed]

14. Domingues, P.M.; Santos, L. Essential oil of pennyroyal (Mentha pulegium): Composition and applications as alternatives to pesticides-New tendencies. Ind. Crop. Prod. 2019, 139, 111534. [CrossRef]

15. Sharma, A.; Shukla, A.; Attri, K.; Kumar, M.; Kumar, P.; Suttee, A.; Singh, G.; Barnwal, R.P.; Singla, N. Global trends in pesticides: A looming threat and viable alternatives. Ecotoxicol. Environ. Saf. 2020, 201, 110812. [CrossRef] [PubMed]

16. Sayed, S.M.; Alotaibi, S.S.; Gaber, N.; Elarrnaouty, S.-A. Evaluation of five medicinal plant extracts on Aphis craccivora (Hemiptera: Aphididae) and its predator, Chrysoperla Carnea (Neuroptera: Chrysopidae) under laboratory conditions. Insects 2020, 11, 398. [CrossRef] [PubMed]

17. Fernández-Grandon, G.M.; Harte, S.J.; Ewany, J.; Bray, D.; Stevenson, P.C. Additive effect of botanical insecticide and entomopathogenic fungi on pest mortality and the behavioral response of its natural enemy. Plants 2020, 9, 173. [CrossRef] [PubMed]

18. Dias, M.L.; Auad, A.M.; Magno, M.C.; Resende, T.T.; Fonseca, M.G.; Silva, S.E.B. Insecticidal activity of compounds of plant origin on Mahanarva spectabilis (Hemiptera: Cercopidae). Insects 2019, 10, 360. [CrossRef] [PubMed]

19. Gu, R.; Morcol, T.; Liu, B.; Shi, M.; Kennelly, E.J.; Long, C. GC-MS, UPLC-QTOF-MS, and bioactivity characterization of Acer truncatum seeds. Ind. Crop. Prod. 2019, 138, 111480. [CrossRef]

20. Zhang, C.; Zhang, Q.; Zhong, C.; Guo, M. Volatile fingerprints and biomarkers of three representative kiwifruit cultivars obtained by headspace solid-phase microextraction gas chromatography mass spectrometry and chemometrics. Food Chem. 2019, 271, 211-215. [CrossRef]

21. Rampadarath, S.; Puchooa, D.; Jeewon, R. Jatropha curcas L: Phytochemical, antimicrobial and larvicidal properties. Asian Pac. J. Trop. Bio. 2016, 6, 858-865. [CrossRef]

22. Xing, S.; Peng, C.; Wang, M.; Peng, Y.; Li, X. Ultra-performance liquid chromatography/quadrupole time-of-flight mass spectrometry analysis of In vitro metabolites of lignans from fructus forsythiae by Human Fecal Flora. Pharmacogn. Mag. 2018, 14, 364. [CrossRef]

23. Chen, G.; Zhao, W.; Li, Y.; Zhou, D.; Ding, J.; Lin, B.; Li, W.; Yang, Y.; Liu, J.; Hou, Y.; et al. Bioactive chemical constituents from the seed testa of Vernicia fordii as potential neuroinflammatory inhibitors. Phytochemistry 2020, 171, 112233. [CrossRef] [PubMed]

24. Petrillo, A.D.; González-Paramás, A.M.; Rosa, A.; Ruggiero, V.; Boylan, F.; Kumar, A.; Pintus, F.; Santos-Buelga, C.; Fais, A.; Era, B. Chemical composition and enzyme inhibition of Phytolacca dioica L. seeds extracts. J. Enzym. Inhib. Med. Chem. 2019, 34, 519-527. [CrossRef]

25. Waibel, R.; Benirschke, G.; Benirschke, M.; Achenbach, H. Sesquineolignans and other constituents from the seeds of Joannesia princeps. Phytochemistry 2003, 62, 805-811. [CrossRef]

26. Yasmeen, F.; Szmigielski, R.; Vermeylen, R.; Gómez-González, Y.; Surratt, J.D.; Chan, A.W.H.; Seinfeld, J.H.; Maenhaut, W.; Claeys, M. Mass spectrometric characterization of isomeric terpenoic acids from the oxidation of $\alpha$-pinene, $\beta$-pinene, $d$-limonene, and $\Delta^{3}$-carene in fine forest aerosol. J. Mass Spectrom. 2011, 46, 425-442. [CrossRef] [PubMed]

27. Papazian, S.; Parrot, D.; Burýšková, B.; Weinberger, F.; Tasdemir, D. Surface chemical defence of the eelgrass Zostera marina against microbial foulers. Sci. Rep. 2019, 9, 1-12. [CrossRef]

28. Attygalle, A.B.; Ruzicka, J.; Varughese, D.; Bialecki, J.B.; Jafri, S. Low-energy collision-induced fragmentation of negative ions derived from ortho-, meta-, and para-hydroxyphenyl carbaldehydes, ketones, and related compounds. J Mass Spectrom. 2007, 42, 1207-1217. [CrossRef] [PubMed]

29. Hu, J.S.; Gelman, D.B.; Salvucci, M.E.; Chen, Y.P.; Blackburn, M.B. Insecticidal activity of some reducing sugars against the sweet potato whitefly, Bemisia tabaci, biotype B. J. Insect Sci. 2010, 10, 203. [CrossRef]

30. Shanmugavel, S.; Velayutham, V.; Kamalanathan, T.; Periasamy, M.; Munusamy, A.; Sundaram, J. Isolation and analysis of mannose/trehalose/maltose specific lectin from jack bean with antibruchid activity. Int. J. Biol. Macromol. 2016, 91, 1-14. [CrossRef]

31. Küçükaydın, S.; Tel-Çayan, G.; Duru, M.E.; Kesdek, M.; Öztürk, M. Chemical composition and insecticidal activities of the essential oils and various extracts of two Thymus species: Thymus cariensis and Thymus cilicicus. Toxin Rev. 2020, 1-11. [CrossRef]

32. Yang, X.L.; Jiang, M.Y.; Hsieh, K.L.; Liu, J.K. Chemical constituents from the seeds of Morinda citrifolia. Chin. J. Nat. Med. 2009, 7, 119-122. [CrossRef]

33. de Barros, R.P.; Reis, L.S.; da Costa, J.G.; Cunha, A.L.; Magalhaes, I.C.S.; da Silva, C.G.; dos Santos, A.F.; das Neves, J.D.S.; Duarte, A.G.; de Mello, G.S.V.; et al. Bioactivity and phenolic composition of extracts of noni (Morinda citrifolia L., Rubiaceae) in tomato moth (Tuta absoluta Meyrick, 1917) (Lepidoptera: Gelechiidae). Afr. J. Agric. Res. 2018, 13, 2063-2069. [CrossRef]

34. Ishibashi, F.; Taniguchi, E. Synthesis and absolute configuration of the insecticidal sesquilignan (+)-HAEDOXAN a in honour of professor G. H. Neil Towers 75th birthday. Phytochemistry 1998, 49, 613-622. [CrossRef] 
35. Taniguchi, E.; Imamura, K.; Ishibashi, F.; Matsui, T.; Nishio, A. Structure of the novel insecticidal sesquilignan, haedoxan a. Agric. Biol. Chem. 1989, 53, 631-643. [CrossRef]

36. Chauhan, N.; Kumar, P.; Mishra, S.; Verma, S.; Malik, A.; Sharma, S. Insecticidal activity of Jatropha Curcas extracts against housefly, Musca domestica. Environ. Sci. Pollut. Res. Int. 2015, 22, 14793-14800. [CrossRef]

37. Silva, G.N.; Faroni, L.R.A.; Sousa, A.H.; Freitas, R.S. Bioactivity of Jatropha Curcas L. to insect pests of stored products. J. Stored. Prod. Res. 2012, 48, 111-113. [CrossRef]

38. Li, X.; Li, L.; Wang, J.; Wang, T.; Wang, L. Two new lignans with antioxidative activities from Jatropha Curcas. Nat. Prod. Res. 2014, 28, 1985-1991. [CrossRef]

39. Łyczko, J.; Masztalerz, K.; Lipan, L.; Lech, K.; Carbonell-Barrachina, Á.A.; Szumny, A. Chemical determinants of dried Thai basil (O. basilicum var. thyrsiflora) aroma quality. Ind. Crop. Prod. 2020, 155, 112769. [CrossRef]

40. Zhang, L.; Jia, B.; Tan, X.; Thammina, C.S.; Long, H.; Liu, M.; Wen, S.; Song, X.; Cao, H. Fatty acid profile and unigene-derived simple sequence repeat markers in tung tree (Vernicia fordii). PLoS ONE 2014, 9, e105298. [CrossRef]

41. Kumar, S.; Dhillon, M.K.; Singh, M.; Rathi, R.S.; Misra, A.K.; Rana, J.C. Fatty and amino acid compositions of Vernicia fordii: A source of $\alpha$-eleostearic acid and methionine. Indian J. Exp. Biol. 2017, 55, 734-739.

42. Cui, S.; Tan, S.; Ouyang, G.; Jiang, S.; Pawliszyn, J. Headspace solid-phase microextraction gas chromatography-mass spectrometry analysis of Eupatorium odoratum extract as an oviposition repellent. J. Chromatogr. B 2009, 877, 1901-1906. [CrossRef]

43. Chaubey, M.K. Biological activities of Zingiber officinale (Zingiberaceae) and Piper cubeba (Piperaceae) essential oils against pulse beetle, Callosobruchus chinensis (Coleoptera: Bruchidae). Pak. J. Biol. Sci. 2013, 16, 517-523. [CrossRef] [PubMed]

44. Babu, G.D.K.; Dolma, S.K.; Sharma, M.; Reddy, S.G.E. Chemical composition of essential oil and oleoresins of Zingiber officinale and toxicity of extracts/essential oil against diamondback moth (Plutella xylostella). Toxin Rev. 2020, 39, 226-235. [CrossRef]

45. Ma, X.; Wang, L.; Yang, M.; Hao, F. Insecticidal activity and active components of Cynanchi auriculati against Plutella xylostella. Agrochemicals 2009, 48, 261-264. [CrossRef] 